\title{
MISTRZ I MAŁGORZATA ŹRÓDŁEM INSPIRACJI W KSZTAŁTOWANIU WARTOŚCI W PROCESIE WYCHOWANIA
}

\begin{abstract}
Abstrakt: Czytanie utworów literackich daje możliwość poznania różnych kwestii związanych z własnym rozwojem, wzbogaca proces myślenia i przeżycia. To na gruncie przeżycia intelektualnego rozpoczyna się wychowawcze oddziaływanie literatury, która motywuje do przemyśleń i wartościowania. Metafory i symbole zawarte w tekście pozwalają na przeprowadzenie emocjonalnego wglądu w siebie i uświadomienie tego, co można zrobić. Pojawia się sugestia mentalna, a więc myśl, która prowadzi do zmiany danej postawy i przyjęcia nowych wartości. Proces wychowawczy w kształtowaniu wartości może być wspierany czytaniem literatury. Artykuł ukazuje możliwość poszerzania procesu wychowania przez czytanie i analizę książki Mistrz i Małgorzata.
\end{abstract}

Słowa kluczowe: utwór literacki, biblioterapia, wartości, proces wychowania

\section{WPROWADZENIE}

Pojęcie „wartość” jest utożsamiane z tym, co jest cenne, godne pożądania, co łączy się z pozytywnymi przeżyciami i stanowi cel, do którego warto dążyć (Łobocki 1993, s. 125). Dla niektórych wartość stanowią przedmioty materialne, dla innych zaś przekonania, idee. Im bardziej są one pożądane, tym większą mają wartość. Stają się silnym bodźcem i inspirują do różnorakich działań. Wprowadzanie w świat wartości to kształtowanie określonych potrzeb, upodobań, dążeń.

W literaturze przedmiotu zawarto wiele interpretacji pojęcia „wartość”. W jednej z nich, przedstawionej przez Renatę Siemieńską, przyjmuje się, że wartości nie są bezpośrednio obserwowalne, lecz obejmują komponent moralny. Są koncepcjami tego, co jest pożądane przez jednostki (Siemieńska 2007, s. 61). Zdaniem Janusza 
Homplewicza „wartością jest wszystko to, co dla człowieka przedstawia się jako cenne, w co chce angażować swoje wysiłki i wolę. To dążenie ku wartościom kształtuje człowieka, jest też w stanie przesądzać o jego wewnętrznym rozwoju, o jego przeżyciach, działaniach i całej postawie życiowej" (Homplewicza 1996, s. 15). Zbigniew Skorny podał, że wartości stanowią względnie trwały składnik osobowości człowieka, zaś ich miernikiem jest natężenie pragnienia posiadania jakiegoś przedmiotu, osiągnięcia upragnionego stanu, nawiązania bliskich kontaktów z określonymi osobami lub grupami społecznymi (Skorny 2000, s. 114).

Z kolei Maria Misztal, zaznaczając, że pojęcie „wartość” ma wiele różnych znaczeń, wyróżniała trzy kategorie definicji:

1) o charakterze psychologicznym - opisujące wartości jako elementy systemu przekonań jednostki o nienormatywnym/normatywnym charakterze, stanowiące przekonania innych ludzi na temat stanu psychicznego, fizycznego i działań jednostki uważnych za godne pożądania oraz jako przedmiot, który zaspokaja potrzeby jednostki, bądź jako zdolność przedmiotu do zaspokojenia potrzeb, które mogą powstać w zetknięciu $\mathrm{z}$ tym przedmiotem;

2) o charakterze socjologicznym - ujmujące wartości jako przedmioty i przekonania o nienormatywnym charakterze, determinujące względnie podobne przeżycia psychiczne i działania jednostek - członków grup społecznych. Wartości tak pojmowane są zewnętrzne wobec jednostki, mają charakter obiektywny. Także wartości ujmowane jako przekonania jednostek lub w grupach społecznych, określające cechy godne pożądania;

3) o charakterze kulturowym - ukazują wartości jako powszechnie pożądane przedmioty o symbolicznym lub niesymbolicznym charakterze oraz jako akceptowane w społeczeństwie sądy egzystencjalno-normatywne (Misztal 1980, s. 14).

Zygmunt Mysłakowski zaznaczył, że rozumienie wartości w kontekście psychologicznym to także przeżycie znaczenia jakiejś rzeczy. Przy czym rzeczy stanowią wartość w momencie, gdy odpowiadają zapotrzebowaniu lub gotowości do ich przeżycia, zaś w przeciwnym wypadku nie są wartością (Mysłakowski 2005, s. 63). Natomiast na wartości w aspekcie socjologicznym uwagę zwrócili William I. Thomas i Florian Znaniecki (Thomas, Znaniecki 2006, s. 61). Według nich wartość społeczną stanowi przedmiot posiadający empiryczną treść, dostępną członkom grupy oraz mającą znaczenie, wskutek którego jest lub może być obiektem działalności. W ten sposób artykuł żywnościowy, instrument, moneta, utwór literacki, uniwersytet, teoria naukowa są wartościami społecznymi. Należą do nich także sądy jednostkowe lub zbiorowe oparte na normach i zasadach (Wiśniewski 2008, s. 24). Definicje słowa „wartość” o charakterze kulturowym lokują je w rzeczywistości 
kulturowej sui generis bez odnoszenia się do konkretnych jednostek, np. są to powszechnie pożądane przedmioty o symbolicznym lub niesymbolicznym charakterze, akceptowane sądy egzystencjonalno-normatywne, przekonania i zachowania członków społeczeństwa (Misztal 2000, s. 19).

Analizując definicje wartości w relacji wobec ludzi i ich cech, Gerhard Kloska wyróżnił ich pięć rodzajów:

1. Relatywistyczne, które są zależne od określonej cechy lub zespołu cech (względnych). Aby cokolwiek mogło być wartością, musi pozostawać w pewnym stosunku do jakiegoś podmiotu.

2. Subiektywistyczne - wartości utożsamia się wyłącznie z pewnymi cechami przedmiotów. Są one cechami subiektywnymi, tzn. przysługują wyłącznie podmiotom - cechy podmiotu są wartościami, służą zaspokojeniu potrzeb.

Zarówno relatywistyczne, jak i subiektywistyczne definicje za wartość uważają następujące cechy: myśl, pojęcie, koncepcja, przekonanie, wyobrażenie, motywacja. W przypadku definicji relatywistycznych cechy te sprawiają, że pewne przedmioty są wartościami, natomiast w przypadku definicji subiektywistycznych same cechy stają się wartościami.

3. Relacjonistyczne, w których utożsamia się wartość ze szczególnego rodzaju relacjami, stosunkami, związkami między jednostkami (ich cechami) bądź grupami a przedmiotami.

4. Instrumentalne - nacisk kładzie się na to, czemu służą wartości.

5. Kulturowe - lokują wartości w rzeczywistości kulturowej, bez odnoszenia ich do konkretnych jednostek (Kloska 1982, s. 42-58).

Termin „wartość” jest pojęciem niezwykle wieloznacznym i nieostrym. Nie występuje pojedynczo, lecz pojawia się w określonych układach, które na podstawie danej teorii tworzą powiązania w tzw. system wartości (Misztal 2000, s. 16-17). Każdy system ma określoną budowę oraz zespół związków o charakterze funkcjonalnym, ewentualnie uporządkowanym, a także może być powiązany $\mathrm{z}$ innymi wartościami (Koralewicz-Ziębik 2004, s. 47-48). Niezwykle ważny jest fakt, że pewne wartości zajmują miejsce naczelne i cenione, zaś inne funkcjonują jako element pomocniczy, służący osiąganiu owych nadrzędnych wartości. Wartości naczelne i cenione najczęściej są to wartości autoteliczne, natomiast pomocnicze to wartości instrumentalne (Misztal 2000, s. 16-17).

Charles Taylor pojęcie wartości widział jako standard moralny w wewnętrznie wypracowanym przez wieki poczuciu człowieka, że coś jest dobre, godne akceptacji, „porusza nas mocne poczucie, że ludzie są przede wszystkim godni pomocy, czy też sprawiedliwego traktowania, że posiadają godność i wartość. Tu właśnie 
dochodzimy do owych moralnych źródeł, stanowiących pierwotne fundamenty owych standardów" (Taylor 2001, s. 948).

Należy zaznaczyć, że kwestie etyczne stały się współcześnie problemami par excellence pedagogicznymi i przestały być udziałem elit intelektualnych, i dotyczyć wąskich dyscyplin filozoficznych. Pedagogika jest szczególnie powołana do podejmowania i pilotowania takiego dyskursu, który stał się jedną z głównych jej dziedzin, zarówno przez rozwój aksjologii wychowania, jak i przez analizy przekazu kulturowego, interakcji społecznych oraz wyłanianych w nich wartości (Nowicka-Kozioł 2007, s. 17).

\section{ZNACZENIE WARTOŚCI W WYCHOWANIU}

Proces opiekuńczo-wychowawczy nie może istnieć bez wprowadzania w świat wartości i wytworów duchowych. Stanowią one źródło jego inspiracji i wytycznych. Zawarte są zarówno w celach, treściach, jak i metodach działania. Tworzone i realizowane w edukacji szkolnej systemy wartości stają się drogowskazem wyznaczającym prawidłowe funkcjonowanie w świecie społecznym (Karwatowska 2010, s. 13).

Wartości pojawiają się jako system norm rzutujących na poczynania zarówno nauczyciela, jak i uczniów. Nauczanie i wychowanie za podstawę przyjmują uniwersalne zasady etyki, które mają służyć rozwijaniu „poczucia odpowiedzialności, miłości ojczyzny oraz poszanowania polskiego dziedzictwa kulturowego, przy jednoczesnym otwarciu na wartości kultury Europy i Świata. Szkoła powinna zapewnić każdemu uczniowi warunki niezbędne dla jego rozwoju, przygotować go do wypełnienia obowiązków rodzinnych i obywatelskich w oparciu o zasady solidarności, demokracji, tolerancji, sprawiedliwości i wolności" (Ustawa z dnia 7 września 1991 r. o systemie oświaty). W procesie wychowania i samowychowania niezbędna staje się aksjologia zarówno ogólna, jak i pedagogiczna, która ukierunkowuje i wspomaga kształtowanie stosunku do świata, rozumienia praw i powinności, a także jest pomocna $\mathrm{w}$ formułowaniu celów edukacyjnych i życiowych. Edukacja pojmowana jako proces wielostronny i wielofunkcyjny przebiega w trzech wymiarach czasowych: przeszłości, teraźniejszości i przyszłości. Istotne jest przyjęcie określonej hierarchii wartości, która powinna ukazywać ich kolejność usytuowania od wartości podstawowych do najwyższych (Kamiński 2006, s. 7). Ważne jest kształtowane zespołów wartości pozytywnych, z których właściwa wartość mogłaby być wybrana dobrowolnie, z pełnią szacunku do osób i przedmiotów (Hartman 2004, s. 1435).

W procesie wychowania wartości pojawiają się w różny sposób, np. przez poznanie i zrozumienie norm postępowania. Ich akceptacja i przekonanie o słuszności 
staje się warunkiem przeżycia powinności i dostosowania swojego postępowania, co prowadzi do uświadomienia faktu, iż człowiek potrafi decydować o sobie i swoim zachowaniu oraz być sprawcą czynów, za które odpowiada. Wychowanek w procesie wartościowania dokonuje oceny różnych przedmiotów i stanów w odniesieniu do preferowanych wartości. Według własnego uznania oddziela to, co pozytywne od tego, co negatywne. Określone wewnętrzne przeżycia, oceny rzeczy oraz sytuacje implikują przyjmowane wartości (Borkowski 2003, s. 53). Wychowawca będący wzorem osobowym i autorytetem moralnym wychowuje do wartości, szanując autonomię wychowanka. Zachodząca interakcja jest pozbawiona przymusu i stanowi współpracę pomiędzy podmiotami. Pozwala wychowankowi na utożsamianie się z danymi wartościami. Nie istnieje jednolity system wartości, lecz różnorodne typy wartościowania, tworzące kategorie wartości. Tym samym każda jednostka przeżywa wartości tylko we właściwy w sobie sposób (Karwatowska 2010, s. 9). Nie bez znaczenia jest preferowany przez pedagogów system wartości, który staje się wspornikiem w kształtowaniu konkretnych reguł i zasad będących źródłem wszelkich norm aksjologicznych.

\section{WYCHOWAWCZE ODDZIAŁYWANIE LITERATURY}

Włodzimierz Goriszowski zaznaczył, iż „książka, ochocza przedstawicielka wartości, dzieląc się swą treścią, wzbogaca innych bez utraty siebie" (Goriszowski 1973, s. 7). Czytanie utworów literackich daje możliwość poszerzania wiedzy, wzbogacenie myślenia, własnego rozwoju i doznania. Na gruncie przeżycia intelektualnego rozpoczyna się wychowawcze oddziaływanie literatury, motywuje ono do przemyśleń i wartościowania ludzi i zjawisk. Aktywizuje się wówczas wyobraźnia odbiorcy. W odbiorze tekstu przez metaforę i symbole możemy utożsamić się z bohaterem i poddać przeżywanym przez niego emocjom. Dzięki temu czytelnik może przeprowadzić emocjonalny wgląd w siebie, otworzyć się na różnorodne przeżycia i doświadczenia, wejść w świat wartości moralnych i etycznych, rozumieć i odczuwać dobro i zło, to co akceptuje, i to co neguje, a także poznać wartości estetyczne (Grądzka-Tys, Grzegorczyk 2001, s. 146). Ogromną rolę odgrywa słowo, gdyż oddziałując na psychikę, zmienia sposób funkcjonowania. Kształtuje świadomość, organizuje emocje, nadaje znaczenie stworzonym wyobrażeniom, porządkuje myśli (Jankowski 1975, s. 217).

Jak podkreślił Stanisław Bortnowski, „literatura kogoś wychowuje, kogoś znieprawia, wobec kogoś innego przechodzi niezauważalnie” (Bortnowski 2007, s. 16). Dostarcza bogatych materiałów do najrozmaitszych czynności korekcyjno-wychowawczych. Szczególnie oddziałuje na kształtowanie osobowości, rozbudowanie 
sfery przeżyć emocjonalno-wyobrażeniowych, na budowanie świadomości powiązanej z procesami życiowymi. Służy człowiekowi do odnajdywania i przekraczania siebie w procesie autokreacji. Odbywa się to przez procesy świadomości nakierowanej na wewnętrzny „świat człowieka” (Starzec 1980, s. 65, 67). Literatura pokazuje głębię i rozległość, bogactwo odczuć, siłę namiętności, staje się rzeczywistym zwierciadłem człowieka. Odpowiednio odbierana może stymulować wszechstronny rozwój osobowości oraz kształtować postawy i wartości (Gołaszewska 1977).

W dziele literackim artystycznie pojmowana fikcja przechodzi w rzeczywistość, zbliża się z nią, wprowadzając odbiorcę w wielką złożoność życia (Kida 2001, s. 57). Pisarz z jednej strony buduje pewien fikcyjny świat, który jest poznawczo-artystycznym równoważnikiem jakichś zakresów świata realnego, zaś z drugiej stara się przez ten fikcyjny świat dotrzeć do czytelnika, uczynić, aby treść utworu wywarła wpływ na jego stanowisko wobec życia (Głowiński, Okopień-Sławińska, Sławiński 1991, s. 59).

W ostatnich latach w eksploracjach czytelniczych nastąpiły zmiany w poglądach na relację „czytelnik-tekst terapeutyczny”, przenosząc akcent z odbioru intelektualnego na emocjonalny, skupiając się bardziej na podświadomych niż świadomych procesach zachodzących w odbiorcy (Okrasa 2011, s. 207). Joanna Papuzińska zaznaczyła, że dla rozwoju osobowości człowieka, jego zdolności do komunikowania się i radzenia sobie $z$ trudnościami znacznie ważniejsze są emocjonalne przeżycia literackie od zdobywania tylko wiedzy i informacji (Papuzińska 1996, s. 14).

\section{KSIĄŻKA MISTRZ I MAŁGORZATA NOŚNIKIEM WARTOŚCI}

Czytając książkę, wiemy, co jej bohaterowie robią, myślą, czują i to staje się przewodnikiem w życiu, najlepszym sposobem uczenia się, poznania prawdy o sobie. Wyobrażenie przedmiotu, problemu czy bohatera pozwala na przeprowadzenie emocjonalnego wglądu w siebie i uświadomienie, co można jeszcze zrobić. Poznanie uczuć innej osoby i postawienie siebie na jej miejscu pomaga w identyfikacji z tą osobą. Pojawia się sugestia mentalna, a więc myśl, która może prowadzić do zmiany (Krasoń 2000, s. 176-178; Brun, Pedersen, Runberg 1995, s. 140).

Utworem pozwalającym na wypracowanie własnej indywidualnej postawy moralnej, uczenia samoświadomości i odblokowania emocji może być powieść Michała Afanasjewicza Bułhakowa Mistrz i Małgorzata. Jej akcja rozgrywa się w czasie Międzynarodowego Dnia Solidarności Ludzi Pracy. Przewodniczący MOSSOLIT Berlioz śpieszył się na uroczyste spotkanie majowe i od dawna myślał tylko o własnym samopoczuciu, a nie o prawie wolnego pisania. Noc z 30 kwietnia na 1 maja jest Nocą Walpurgii, znaną też jako wielki szabat czarownic odbywający się na 
górze Brocken - akurat po tej nocy Woland ${ }^{1}$ przybył do Moskwy. Podstawą powieści jest powiązanie bohaterów według statusu społecznego, nie zaś więzi pokrewieństwa. Wartość ludzkiej osobowości nad statusem społecznym M. Bułhakow pokazał na przykładzie samego tytułu Mistrz i Małgorzata.

Michał Bułhakow ukazał całą gamę niezapomnianych postaci. Świat ziemski prezentują zwykli ludzie z codziennymi problemami, ludzie zniewoleni, żyjący według ustalonych reguł. Oni nie wierzą w biblijne i nieziemskie wymiary czasowe. W takim społeczeństwie wszystko musi odbywać się na zasadzie: „powinno tak być - nie jest to dozwolone”. Dozwolone było tylko głoszenie dopuszczalnych słów i działanie wyłącznie w konkretnym kierunku. M. Bułhakow żył akurat w takich czasach i bardzo dobrze rozumiał wartość swobody. Jego powieść ${ }^{2}$ jest wyjątkową pracą, w której autor połączył ze sobą mit i rzeczywistość, satyryczne kroniki i romantyczną fabułę, prawdziwe przedstawienie i sarkazm.

W książce poruszono takie życiowe kwestie, jak dobro i zło, zdrada i oszustwo, wolność i zniewolenie, miłość i nienawiść, prawda i kłamstwo. Autor również pokazał cztery różne światy: ziemia, światłość, ciemność, spokój. Wiosną podróż doprowadziła Wolanda do Moskwy lat 30. XX wieku - do takiego miejsca, w którym nikt nie wierzył ani w Szatana, ani w Boga, co zaprzecza istnieniu Jezusa Chrystusa w historii. Obraz Moskwy stał się ilustracją Radzieckiej Rosji. W Moskwie Woland spotkał się z tytułowym bohaterem Mistrzem, który napisał powieść o ostatnich dniach Jeszui. Mistrz przebywał w zakładzie psychiatrycznym, dlatego że czcił swój utwór ostro skrytykowany przez cenzurę. Małgorzata zaś była żoną „wybitnego specjalisty", ukochaną Mistrza, którego nie mogła znaleźć po tym, jak trafił on do zakładu psychiatrycznego, a chciała tylko go odzyskać. Nadzieję na spełnienie tego marzenia dał Asasello - Małgorzata w zamian musiała uczynić Wolandowi jedną przysługę. Początkowo opierała się, ale fakt spotkania się z Mistrzem wpłynął na jej zgodę. Jej zadaniem było poznać wszystkich członków świty Wolanda (szatana) i zostać gospodynią balu. W nocy z piątku na sobotę rozpoczął się bal, na którym nie mogli się znaleźć zwykli grzesznicy, ale tylko prawdziwi, ideologiczni złoczyńcy.

W powieści postać Mistrza nie jest jasno przedstawiona. Jednak to on rozwiązał główny dylemat: zrozumiał, co jest najważniejsze - Dobro czy Zło. Dobroć,

1 Szatan, przywódca grupy przybyłej z zaświatów. W powieści występuje jako profesor tajnej magii lub tajemniczy konsultant, filozof. Wyrozumiały dla ludzi, potrafi być wspaniałomyślny. Wpływa na losy tytułowych bohaterów, nie niszczy, zagraża tylko temu, co zepsute i złe. W powieści staje się też pośrednikiem czynienia dobra wśród ludzi uczciwych i sprawiedliwych. Przede wszystkim karze osoby podły i chciwe.

2 Michaił Afanasjewicz Bułhakow pracował nad powieścią około 11-12 lat, od 1928/1929 do 1940 roku. W trakcie pisania zmieniał koncepcję powieści, jego fabułę, kompozycję oraz nazwę. 
słowami Jeszua - bohatera jego książki - wyzwala człowieka ze zła za pomocą słowa, a nie siłą władzy, bo taka władza jest narzędziem przemocy. Małgorzata jest osobą silną i uczciwą. Ze względu na spotkanie ze swoim ukochanym jest gotowa nawet zostać wiedźmą i być królową na balu u Szatana. Bogactwo i komfort nie są jej potrzebne. Dla niej szczęściem i miłością jest spotkanie z Mistrzem, i w tym odnalazła sens życia.

Miłość w powieści stanowi największa wartość i nadaje jej tajemniczości i wyjątkowości. Jest w stanie wiele zmienić i przeciwstawić się trudnościom. To miłość kierowała Małgorzatą, która dla Mistrza przeszła przez wszystkie przeszkody; wycierpiała upokorzenie na balu, nie mając pewności, że jej życzenie się spełni. Fakt, że sprzedała swoją duszę Diabłu, po raz kolejny udowadnia siłę jej miłości. Zwykłe życie wydawało się jej puste i pewnego wiosennego dnia wyszła „z bukietem żółtych kwiatów właśnie po to, bym [by] ją wreszcie odnalazł” (Bułhakow 1987, s. 177) ten, w którym zakochała się dawno temu. Mistrza zafascynowała nie tyle jej uroda, ile „niezwykła, niesłychana samotność malująca się w oczach” (Bułhakow 1987, s. 176). Nagrodą za cierpienia było dla nich to, że zdobyli wieczne szczęście i spokój.

Jeszua (bohater powieści Mistrza) jest wędrownikiem głoszącym wartości moralne. Otwartość jego umysłu i ducha wychodzi z dobrych intencji, wiary i miłości do człowieka, jest ona niedostępna dla zwykłych śmiertelników. Najważniejszym jego celem jest czynienie dobra i wybaczanie wrogom. Jeszua wstawia się nawet do ducha Zła za Małgorzatą, która oddała swoją duszę Diabłu w imię miłości. Dla niego ważna jest wewnętrzna strona człowieka, którą trzeba rozwijać, wierzy ludziom, mając nadzieję na ich odrodzenie duchowe.

Wszyscy, którzy nawiązywali kontakt z Wolandem i jego świtą, zostali ukarani za swoje grzechy: przekupstwo, pijaństwo, egoizm, chciwość, obojętność, kłamstwo. Często kary te, choć miały nadzwyczajny charakter, były logiczną konsekwencją złego postępowania. I tak, po tym jak Korowiow wręczył Bosemu łapówkę $\mathrm{w}$ radzieckich rublach $\mathrm{w}$ zamian na zameldowanie Wolanda wraz ze świtą w mieszkaniu Lichodiejewa i Berlioza, w domu Bosego pojawiła się milicja, która zamiast rubli znalazła dolary i aresztowała go za spekulacje walutowe. Bosy podczas aresztowania zachował się „dziwnie” i z tego powodu trafił do szpitala psychiatrycznego. Należy również zwrócić uwagę na scenę w teatrze Variétés, gdzie doskonale podkreślono rolę Wolanda. Zamienił to miejsce w laboratorium do badania ludzkich słabości. Tutaj ujawniał prawdziwe oblicze społeczeństwa, jego chciwość oraz mieszczańską wulgarność, co było szczególnie widoczne w momencie, gdy Korowiow (pod pseudonimem Fagot) obsypał publiczność deszczem dziesięciorublowych banknotów, a paniom ofiarował piękne kreacje i obuwie. Następnego dnia banknoty zebrane przez publiczność zamieniły się w różne przedmioty, 
a wymienione ubrania się ulotniły. Dyrektor artystyczny teatru, Stiepan Lichodiejew, pogrążając się w pijaństwie i rozpuście, został przeniesiony przez Wolanda do Jałty, a administrator teatru Iwan Warionucha za kłamstwa głoszone przez telefon stał się wampirem, a następnie powrócił do dawnej pracy jako wzór prawdomówności, o co wcześniej trudno go było podejrzewać.

Typowymi cechami społeczeństwa tych czasów były: chciwość, przekupstwo, żądza, obżarstwo i pijaństwo. Pieniądze jako wartość pozorna zostały ukazane zarówno w świecie nowoczesnym, jak i w realiach starożytności jerozolimskiej. Obojętnym wobec pieniędzy pozostał tylko Woland ze swoją świtą. Juda, który zdradził swego przyjaciela za 30 srebrników, mieszkańcy Moskwy, którzy chętnie chwytali mamonę spadającą z sufitu - wszyscy oni poddawali się tej pozornej wartości. W efekcie Juda został zabity, a mieszkańcy Moskwy dostali dobrą nauczkę za swoje zachowanie, gdy ich pieniądze zamieniły się w czyste kartki, a nowa wymieniona odzież zniknęła $\mathrm{z}$ ich ciał, ukazując ich nagość.

Przedstawiony obraz typowego obywatela składa się z wielu masek, które należą w większym stopniu do bohaterów drugoplanowych, tworzących współczesne środowisko. Bułhakow pokazał duchowy upadek społeczeństwa. Woland nie tylko karał, lecz także miał skłonność do oczyszczenia duchowego tych, którzy jeszcze zachowali resztki sumienia, dawał możliwość wyboru między dobrem a złem. Starał się zmienić ludzi, zmusić, żeby żałowali za swoje błędy. Podobne przeobrażenie nastąpiło w przypadku poety, autora antyreligijnego poematu - Iwana Bezdomnego, który po aresztowaniu w Gribojedowie został odwieziony do kliniki Strawińskiego, skutkiem czego utracił wiarę we własny talent, przestał pisać i został profesorem Instytutu Historii Filozofii.

Michaił Bułhakow chciał pokazać czytelnikom, że świat jest pełen fałszywych wartości i tylko silna osoba może się z tym zmierzyć. Natomiast łatwe pieniądze, zdrada i żądza zysku prowadzą do zła i nieszczęścia innych. Człowiek nie może być szczęśliwy, jeśli dużą ilość czasu traci na wartości pozorne, które niszczą jego życie. Tylko odwieczne zasady moralne mogą ocalić ludzką nieśmiertelną duszę.

Druga płaszczyzna powieści to wątek historyczny rozwijający się równolegle do wątku tytułowego. Jest to powieść o Poncjuszu Piłacie napisana przez Mistrza, skupiona wokół procesu i kaźni wędrownego proroka Jeszui Ha-Nocri, która przyciągała wielu ciekawskich, ogarniętych chciwością ludzi: za wózkiem skazańców „szło ze dwa tysiące gapiów, którzy nie zlękli się piekielnego upału i chcieli zobaczyć ciekawe widowisko. Do tych gapiów z miasta przyłączali się teraz ciekawi spośród pątników" (Bułhakow 1987, s. 220). Pod koniec powieści oba wątki się łączą: Mistrz uwolnił bohatera swojej powieści, a Poncjusz Piłat odnalazł spokój i wybrał się w nieskończoną podróż przy świetle księżyca. Małgorzata i Mistrz, którzy nie mogli odnaleźć się w rzeczywistości, zostali otruci przez Asasella. Ich cielesne 
odpowiedniki zmarły, ale oni sami zmartwychwstali. Na czarnych koniach galopowali z Wolandem i jego świtą do innego świata, gdzie czekał na nich „wieczysty dom” i „wieczny spokój”, który otrzymali „w nagrodę” (w odróżnieniu od wymienionej w powieści „światłości” - innej wersji życia pozagrobowego).

Bułhakow pokazał, że odkrycie prawdy - prawdy o dobru - jest możliwe przez rozmowę, gdy osoby uwikłane w konfliktowe sytuacje nie chcą mieć racji, ale chcą zrozumieć, o co im chodzi i co jest przedmiotem sporów. To odejście od walki jest skierowane na poszukiwanie prawdy. Nie każdy jednak potrafi dojrzeć w człowieku to, co zasługuje na nazwę „dobro”. Ci, którzy nie widzą w sobie ani w innych dobra, w rzeczywistości nie wiedzą, na czym ono polega. Można powiedzieć, że człowiek, który zna dobro, jest dobry i chce dokonywać czynów dobrych, choć nie zawsze mu się to udaje. Każdy, kto zobaczył dobro w człowieku, nie chce go krzywdzić, ale szanować (Ruciński 2007, s. 20-21). Hanna Buczyńska-Garewicz napisała: „Prawda oznacza wszystko to, co drogą wiary potwierdza się jako dobre, a okazuje się też dobre dla określonych, sprecyzowanych celów [...] Posiadanie prawdy jest celem samym w sobie, jest tylko wstępnym środkiem do innych satysfakcji życiowych" (Buczyńska-Garewicz 1975, s. 98-99).

Jednym z głównych warunków ujawnienia prawdy jest porozumienie się ludzi ze sobą, aby zaistniała płaszczyzna kulturowa - wspólny język oraz wspólne doświadczenia. Drugim warunkiem jest uzyskanie wolności oraz postawa otwartości. Wybór prawdy bywa trudny i niejednoznaczny, ale jest to wybór dobra w imię godności człowieka. Prawda, jako wartość w życiu człowieka, w obecnych czasach się zdewaluowała. Ludzie uwikłani w problemy codzienności pogrążają się w liczne kłamstwa, stwarzając pozory prawdy, a osoby posiadające wysoki poziom moralności często są odbierane jako naiwne. Dlatego pytanie Piłata: „Cóż więc jest prawdą?” (Bułhakow 1987, s. 31), tłumaczy się niepewnością człowieka, który często nie wie, kim jest, skąd pochodzi i dokąd zmierza.

Ostatnio można zauważyć tendencje do ostrego oceniania klimatów społecznych. Nagłaśniane przez media fakty agresji budzą odczucie, że jest coraz gorzej. Janusz Korczak już dawno dostrzegł błąd w stanowisku, że na świecie jest więcej zła niż dobra. Przyczyną tego jest fakt, że zło jest krzykliwe i dlatego wydaje się, że jest go więcej (Bińczycka 2007, s. 65). Korczak pisał: „co ma kły i pazury napastuje, co ciche wtula się w siebie" (Korczak 1978, s. 85). Zło ma znak negatywny i wiąże się ze świadomie dysfunkcjonalnym zachowaniem człowieka. W dzisiejszych czasach możemy spotkać zjawiska, takie jak obojętność moralna, czyli brak jakiejkolwiek reakcji na widoczne zło. Niekiedy jest to efekt odczuwanego lęku przed ujemnymi konsekwencjami. Kolejnym zjawiskiem jest moral insanity - „choroba moralna”, która polega na tym, że człowiek wie, że czyni zło, a jednak czyni je i nawet znajduje w tym rozkosz (Gołaszewska 1994, s. 64). Ale wiara w człowieka, mimo że 
czujemy się skrzywdzeni, jest wyrazem elegancji wewnętrznej, ponieważ zawiera w sobie optymizm i poszanowanie godności ludzkiej. Taka postawa jest realizacją od wieków powtarzanych słów pacierza „i odpuść nam nasze winy, jako i my odpuszczamy naszym winowajcom" (za: Bińczycka 2007, s. 67).

Istotę miłości i jej wyznaczników dostrzegamy w zdolności współodczuwania oraz w godności i dobru podmiotu miłości. Dobro eksponuje troskę, opiekę, poczucie odpowiedzialności oraz wzajemny szacunek. Przyjmujemy podmiot miłości takim, jakim jest, z jego zaletami i wadami. Kierujemy się wyznawanym systemem wartości i indywidualnym uwrażliwieniem. Głęboka miłość wzbudza poczucie myślenia kategoriami osoby kochanej. Następuje wówczas proces współodczuwania i przyjęcia aktywnej postawy - aktu dawania. W dawaniu siebie człowiek bogaty wewnętrznie utwierdza się w swoich możliwościach i przydatności. Przynosi mu to zadowolenie i radość. Taki akt dawania wzajemnie wzbogaca oraz wzmacnia poczucie odrębności, uczy dostrzegania swojej tożsamości w perspektywie drugiego człowieka (Gajda 1997, s. 87). Jak pisał Erich Fromm: „Nie jest bogaty ten, kto dużo ma, lecz ten, kto dużo daje. Ten, kto jedynie gromadzi, jest w sferze psychologicznej biednym człowiekiem, niezależnie od tego, ile posiada. Ktokolwiek potrafi dawać z siebie - jest bogaty" (Fromm 1970, s. 31).

Zmiany społeczne nie oznaczają harmonijnego postępu, choć jest on widoczny we wszystkich dziedzinach życia. Dzisiaj siłą negatywną jest fakt, że świat obraca się wokół pieniędzy, odwracając społecznie ukształtowany układ wartości, wynosząc własne interesy nad potrzeby innych ludzi. Mieszanie się dobra i zła wywołuje chaos aksjologiczny, zamęt w systemie wartości (Szymański 2007, s. 51).

Nasza epoka potrzebuje takiej mądrości, która człowieka czyniłaby bardziej ludzkim. Nie można wyeliminować z życia społeczeństwa wartości uniwersalnych. Ważne jest, aby kształtować umiejętność nie tyle karania za przewinienia, ile zrozumienia i przebaczania; wychowywać bez stosowania przemocy, agresji, wrogości i przeciwieństwa (Szymański 2007, s. 51).

Michaił Bułhakow w swojej powieści przedstawił przykład twórczego ducha, czystości, dał wiarę w dobro, w tradycje kulturowe i wartości moralne. Człowiek ma być odpowiedzialny za swoje działania. Dlatego Jeszua Ha-Nocri jest przede wszystkim człowiekiem, nie są dla niego ważne potrzeby fizyczne, ale wartość widzi w życiu duchowym. Są to przekonania, postawy, idee, zasady, do których dotarł własnymi siłami. Żyje w zgodzie z własnym sumieniem i nie ukrywa poglądów osobistych. W swoim czasie próbuje rozwiązać problemy, z którymi spotykamy się we współczesnym społeczeństwie. Jest pewien, że ludzie z upływem czasu i doświadczeń staną się lepsi. 


\section{PODSUMOWANIE}

Ideą powieści jest uczulenie czytelników na sytuacje życiowe, które często są niedostrzegane. Niezbędne jest zrozumienie problemu i dążenie do jego rozwiązania. Nie można uciekać przed trudnościami w poszukiwaniu łatwiejszego sposobu życia. Człowiek ma być odpowiedzialny za swoje zachowanie i postępowanie, musi przeciwstawiać się amoralnemu społeczeństwu. Ważne w tym wypadku jest wsparcie osób bliskich, bo poczucie osamotnienia może źle wpłynąć na funkcjonowanie człowieka.

W powieści zaprezentowano przykłady zasadniczych wartości, bez których nie jest możliwe prawidłowe funkcjonowanie społeczne. Przedstawiono społeczeństwo lekkomyślne i chciwe, bierne wobec niewłaściwych czynników zewnętrznych, które nie zwraca uwagi na problemy innych i nie podejmuje walki ze złem. Tak samo jak Jeszua kiedyś miał nadzieję, że ludzie z upływem czasu będą lepsi - Woland po sprawdzeniu stanu współczesnego społeczeństwa stwierdził, że być może niekiedy miłosierdzie zapuka do ich serc... Koniec powieści może skłonić czytelnika do zastanowienia się nad przyszłym losem bohaterów. Jaką nagrodę otrzymali Mistrz z Małgorzatą - spokój, wolność czy przygasłą pamięć? Każdy może zinterpretować to inaczej, ale po przeczytaniu tej książki w czytelniku pozostaje poczucie ładu i sprawiedliwości.

Michał Bułhakow w powieści Mistrz i Małgorzata ujawnił błędy popełniane przez ludzi w nieprawidłowo funkcjonującym środowisku. Społeczeństwo powinno nauczyć się odpowiedzialności, dobroczynności oraz myślenia nie tylko w ramach własnych potrzeb i interesów. Dzieło literackie pokazuje, że nie można dóbr materialnych wynosić nad wartości duchowe, ponieważ wówczas traci się własną osobowość.

Powieść Mistrz i Małgorzata jest unikalnym arcydziełem światowej literatury. Odczytując ją, czytelnik będzie w stanie bardziej ją zrozumieć i dokonać refleksji. Utwór ten może być różnie interpretowany, ale nie pozostanie wobec niego obojętny. Jednym $\mathrm{z}$ dysonansów w powieści jest fakt, że siły zła są oburzone tym, co się dzieje w społeczeństwie i wkraczają do walki z rządzącymi. Czytając powieść, można zadać pytanie: Co to za życie, jeżeli już nawet Zło obawia się, że Dobro jest tak słabe, że nie ma czym walczyć? Woland przybył do Moskwy, aby sprawdzić stan współczesnego społeczeństwa - bardzo interesowało go to, czy obywatele się zmienili wewnętrznie. Doszedł do wniosku, że natura ludzka nie może przejść szybkiej przemiany: „Ludzie są tylko ludźmi... Prawda, są lekkomyślni... No, cóż... I miłosierdzie zapuka niekiedy do ich serc...” (Bułhakow 1987, s. 159). Ale być może jest to także znak, że za nasze grzechy nastąpi czas zapłaty i nikt jej nie ominie. 


\section{LITERATURA}

Borkowski J. (2003). Podstawy psychologii społecznej. Warszawa.

Bortnowski S. (2007). Jak literatura wychowuje. „Polonistyka” 8.

Brajnina B.J., Dmitriewa A.N. (1966). Советские писатели. Автобиографии, Художественная литература. Т. 3. Москва.

Brun B., Pederson E., Runberg M. (1995). Symbole dusz. Tłum. A. Hunce-Bednarska. Warszawa.

Buczyńska-Garewicz H. (1975). Uczucia i rozum w świecie wartości: $z$ historii filozofii wartości. Wrocław.

Bułhakow M.A. (1987). Mistrz i Małgorzata. Tłum. I. Lewandowska, W. Dąbrowski. Warszawa.

Cassirer E. (1971). Esej o człowieku: wstęp do filozofii kultury. Tłum. A. Staniewska. Warszawa.

Drawicz A. (1990). Mistrz i diabeł: o Michale Buthakowie. Kraków.

Dyczewski L. (1995). Kultura polska w procesie przemian. Lublin.

Edukacja - jest $w$ niej ukryty skarb. (1998). Raport dla UNESCO Międzynarodowej Komisji ds. Edukacji dla XXI wieku. Warszawa.

Fromm E. (1970). Ucieczka od wolności. Tłum. O. i A. Ziemilscy. Warszawa.

Gajda J. (1997). Wartości w życiu człowieka: prawda, miłość, samotność. Lublin.

Głowiński M., Okopień-Sławińska A., Sławiński J. (1991). Zarys teorii literatury. Warszawa.

Gołaszewska M. (1977). Człowiek w zwierciadle sztuki: studium z pogranicza estetyki $i$ antropologii filozoficznej. Warszawa.

Gołaszewska M. (1994). Fascynacja złem: eseje z teorii wartości. Warszawa-Kraków.

Goriszowski W. (1973). Książka a wychowanie. Katowice.

Grądzka-Tys A., Grzegorczyk B. (2001). Walory dydaktyczno-wychowawcze lektur szkolnych i tekstów literackich oraz ich integrujaca rola $w$ edukacji wczesnoszkolnej. W: J. Kida (red.). Literatura i sztuka a wychowanie. Rzeszów.

Hartman N. (2004). Najważniejsze problemy etyki. „Znak” 11.

Hmplewicz J. (1996). Etyka pedagogiczna. Rzeszów.

Jankowski K. (1975). Od psychiatrii biologicznej do humanistycznej. Warszawa.

Kamiński S. (2006). Jak uporządkować rozmaite koncepcje wartości. W: S. Sawicki, W. Panas (red.). O wartościowaniu $w$ badaniach literackich. Lublin.

Karwatowska M. (2010). Uczeń w świecie wartości. Lublin.

Kida J. (2001). Literatura piękna czynnikiem inspirującym wrażliwość moralna i estetyczna. W: Literatura i sztuka a wychowanie. Rzeszów.

Kloska G. (1982). Pojęcia, teorie i badania wartości w naukach społecznych. Warszawa. 
Koralewicz-Ziębik J. (2004). System wartości a struktura społeczna. Wrocław. Korczak J. (1978). Pisma wybrane. T. 1. Warszawa.

Krasoń K. (2000). Rozumienie i wyjaśnianie przeżywanego tekstu a komunikacja metaforyczna w pracy z dzieckiem potrzebującym wsparcia. W: B. Kaja (red.). Wspomaganie rozwoju dziecka. Psychostymulacja i psychoreakcja. T. 2. Bydgoszcz.

Łosiew W.I., Petelin W.W. (1989). Михаил Булгаков. Письма: жизнеописание в документах. Москва.

Misztal M. (1980). Problematyka wartości w socjologii. Warszawa.

Mysłakowski Z. (2005). Wychowanie człowieka w zmiennej społeczności. Warszawa. Nowicka-Kozioł M. (2007). Mądrość i głupota - refleksja nad sposobem dochodzenia do prawdy. W: M. Nowicka-Kozioł (red.). Człowiek, wartości, pedagogika. Kraków.

Okrasa M. (2011). Biblioterapia w pracy z dziećmi i młodzieżą. W: D. Wosik-Kawala, T. Zubrzycka-Maciąg. Kompetencje diagnostyczne i terapeutyczne nauczyciela. Kraków.

Papuzińska J. (1996). Dziecko w świecie emocji literackich. Warszawa.

Pietrowski M.S. (2004). Mistrz i Miasto: kijowskie konteksty Michaiła Bułhakowa. Tłum. z jęz. ros. I. Kuźmina, A. Jezierska. Poznań.

Ruciński S. (2007). Problem wartości a ważność osoby. W: M. Nowicka-Kozioł (red.). Człowiek, wartości, pedagogika. Kraków.

Rumiński A. (2007). Od godności do zgodności człowieka. W: M. Nowicka-Kozioł (red.). Człowiek, wartości, pedagogika. Kraków.

Siemieńska R. (2007). Wartości i postawy warunkujące obecność kobiet na rynku pracy. W: R. Siemieńska (red.). Wokół problemów zawodowego równouprawnienia kobiet i mężczyzn. Warszawa.

Skorny Z. (2000). Psychologia wychowawcza. Warszawa.

Starzec H. (1980). Wychowanie literackie. Warszawa.

Szmyd J. (1998). Charakter narodowy i duchowość wspólnoty: szkice teoretyczne. Kraków.

Szymański M.J. (2007). Edukacja jako wartość w warunkach gwałtownej zmiany społecznej. W: M. Nowicka-Kozioł (red.). Człowiek, wartości, pedagogika. Kraków.

Taylor Ch. (2001). Źródła podmiotowości: narodziny tożsamości nowoczesnej. Tłum. M. Gruszczyński. Warszawa.

Thomas W.I., Znaniecki F. (2006). Chłop polski w Europie i Ameryce. T. 1. Warszawa. Wiśniewski W. (2008). Wykształcenie w systemie wartości społeczeństwa polskiego (przemiany w latach 1977-1988). „Studia Socjologiczne” 1.

Zemskaja E.A. (2004). Михаил Булгаков и его родные: Семейный портрет. Языки славянской культуры. 


\title{
NETOGRAFIA
}

Ustawa z dnia 7 września 1991 r. o systemie oświaty, [online] http://www.prawo. vulcan.edu.pl/przegdok.asp?qdatprz=akt\&qplikid=1 (dostęp: 30.10.2013).

\section{THE MASTER AND MARGARITA AS A SOURCE OF INSPIRATION IN SHAPING VALUES IN EDUCATIONAL PROCESS}

\begin{abstract}
Reading literary works gives the opportunity to explore various issues related to one's own development, enriches the process of thinking and experience. It is on the basis of intellectual experience where the educational impact of literature begins, motivating to reflection and evaluation. Metaphors and symbols in the text allow the performance of emotional insight in oneself and realization of what can be done. A mental suggestion appears which is a thought leading to a change in the attitudes and acceptance of new values. Educational process in shaping the values may be supported by reading literature. The article presents the opportunity to broaden the process of upbringing through reading and analysing the book The Master and Margarita.
\end{abstract}

Keywords: literary work, bibliotherapy, the process of upbringing 
